\title{
The Analysis of Factors Related to Feeding Pattern on Child With Undernutrition and Malnutrition Based on Transcultural Nursing Theory
}

\author{
Firda Isnantri \\ Faculty of Nursing, Universitas Airlangga \\ Surabaya, Indonesia \\ Firda.isnantri-2016@fkp.unair.ac.id
}

\author{
Kristiawati \\ Faculty of Nursing, Universitas Airlangga \\ Surabaya, Indonesia \\ $\underline{\text { kristiawati@fkp.unair.ac.id }}$ \\ Retnayu Pradanie \\ Faculty of Nursing, Universitas Airlangga \\ Surabaya, Indonesia \\ Retnayu.pradanie@fkp.unair.ac.id
}

\begin{abstract}
The problem of children suffering from undernutrition and malnutrition are still found in Surabaya, especially at Puskesmas Sawah Pulo. It is caused by the unproper feeding pattern given by their mother. Transcultural nursing theory focuses on factors affecting the culture associated with feeding pattern. The purpose of this study is to analyze factors associated with feeding patterns in undernutrition and malnutrition referring to transcultural nursing theory. The design of study used cross sectional method. There were 33 respondents who were chosen by simple random sampling in this study. The variables in this study were the education, economic, cultural value and lifestyle, social and family support, technology, and feeding pattern. The data were collected by questionnaires and structured interview then it was tested by using the Spearman rho rank test with $\alpha=0.05$. The results showed that there was a relationship between feeding pattern with the economy $(p=0.000 ; r=0.727)$, cultural value and lifestyle $(p=$ $0.001 ; r=0.548)$, and technology $(p=0.006 ; r=0.466)$. However, there was no relationship between feeding pattern and knowledge $(p=0.551)$, social support and family $(p=0.071)$. In conclusion, the economic, social and cultural value, and technological factors affected feeding pattern. Hopefully, health workers can improve preventive and promotive efforts by providing health education to mothers and families, so that the number of undernutrition and malnutrition can be reduced.
\end{abstract}

Keywords—undernutrition; malnutrition; feeding pattern;

\section{INTRODUCTION}

Malnutrition is a problem that often occurs in children aged 15 years, or who is often called the toddler, and the issue is a major cause of death in children in developing countries [1]. Malnutrition in weight according to age is classified as overweight, undernutrition, and malnutrition. A case of children suffering from undernutrition and malnutrition are still commonly found in Surabaya, especially at Puskesmas Sawah Pulo. Causes of that issue are their mother whose action and attitude to apply child's feeding patterns are less precise.
Mothers usually give a menu for children incompletely, such as rice with vegetable instead of soup and dishes. It has become a habit hereditary in feeding children every day even though the government and health workers have socialized monthly about how to provide a meal healthy. Culture affects a person in selecting and eating foods that will be consumed [2]. Theory of transcultural nursing describes nursing based on the understanding of the differences in cultural values inherent in a society which consists of the causes of people's behavior are education, economic, regulation and policy, cultural value and lifestyle, social and family support, religion and philosophy, and technology [3]. Transcultural nursing theory can be used to determine the factors that affect feeding patterns on undernutrition and malnutrition culturally.

Malnutrition contributed $60 \%$ of the causes 11 million toddler deaths worldwide each year in developing countries

[4]. Prevalence in East Java in 2014 showed malnutrition at $4.9 \%$ and $14.2 \%$ for undernutrition. In 2014, Health Department of Surabaya noted 1,526 children with nutritional status Under Red Line (BGM) and Semampir District was the highest BGM number of children in Surabaya at 216 toddlers [5].

Toddlers grow and develop under parents' supervision. Mother has an important role for giving care and educating toddlers to grow and develop the quality of children [6]. Mothers should concern about nutrition consumed by children so that children will grow and develop normally as their age. Proper nutrition is a balanced nutrition such as rice, vegetables, dishes, fruits, and milk, with the amount and frequency feeding according to their age [5]. If the nutrition is less than the body needs, it will cause the body thin and some negative effects such as slow growth of the body, decreasing level of intelligence, and mental disorder even death [7]. Application of feeding by mother can be influenced by culture, value, belief, and individual or group's habit that is in accordance with the Transcultural Nursing Theory [3]. 
Efforts to determine the factors of feeding patterns in undernutrition may not use the Transcultural care that emphasizes the significant role of nursing in the implementation of culture-based nursing interventions in promoting feeding culture correctly as well as their age and nutritional needs of toddler. The transcultural nursing theory stated there are seven factors influencing the feeding patterns culturally [3]. Based on the above, it is necessary to do further research to analyze the factors (education, economy, cultural values and lifestyle, social support and family, and technology) related to the feeding pattern with undernutrition status using Transcultural nursing theory.

\section{METHOD}

This research used descriptive research design with crosssectional approach. The population in this study were all mothers who have children with undernutrition and malnutrition status based on KMS (Card Towards Healthy). The respondent are 35 mothers at Puskesmas Sawah Pulo in April 2016. The sampling is collected by simple random sampling technique. This technique calculated the total amount of sample at 33 people. The independent variables are education, economic, cultural values and lifestyle, social and family support, and technology, while the dependent variable are the feeding patterns. This study used questionnaire as the instrument. The relationship among all variables with ordinal scale data were tested using Spearman Rank Correlation Test by - value $\leq 0.05$.

\section{RESULT}

The demographic characteristics of respondents can be seen from the age of respondents, mostly respondents is 20-35 years at $76 \%$. 25 Respondents who graduated from elementary school is dominant with its percentage at 76. Moreover, the other contributing variables for number of family's member and number of children are $\leq 5$ people and $\leq 2$ people respectively.

Table 2 shows the most dominant variable for respondent's education at Puskesmas Sawah Pulo is mothers who have a good education, but their feeding patterns is not appropriate. Based on the results of statistical analysis using Spearman's rho correlation test with $\alpha<0.05$ in correlation result gets value $=0.108$ and 0.551 . value $=0.551$ is greater than 0.05 , which means that the hypothesis is rejected. The statistical results indicates there is no correlation between knowledge and feeding patterns.

Table 3 illustrates among all respondents, mother with low economy background is the highest number at applying feeding pattern incorrectly. Based on the results of statistical analysis using Spearman's rho correlation test with $\alpha<0.05$ in correlation result gets value $=0.727$ and $=0.000$. value $=$ 0.000 is less than 0.05 , which means the hypothesis is accepted.
TABLE I. DEMOGRAPHIC CHARACTERISTICS OF RESPONDENTS

\begin{tabular}{|c|c|c|c|}
\hline $\begin{array}{l}\text { Demographic } \\
\text { Characteristics of } \\
\text { Respondents }\end{array}$ & Category & $\mathbf{f}$ & $\%$ \\
\hline \multirow[t]{3}{*}{ 1. Age of mother } & $<20$ & 3 & $9 \%$ \\
\hline & $20-35$ & 25 & $76 \%$ \\
\hline & $>35$ & 5 & $15 \%$ \\
\hline \multicolumn{2}{|l|}{ Total } & 33 & $100 \%$ \\
\hline \multirow{4}{*}{$\begin{array}{l}\text { 2. Education } \\
\text { Background }\end{array}$} & SD / equivalent & 25 & $76 \%$ \\
\hline & SMP / equivalent & 6 & $18 \%$ \\
\hline & $\begin{array}{l}\text { High School / } \\
\text { equivalent }\end{array}$ & 2 & $6 \%$ \\
\hline & Academy/College & 0 & $0 \%$ \\
\hline \multicolumn{2}{|l|}{ Total } & 33 & $100 \%$ \\
\hline \multirow{2}{*}{$\begin{array}{l}\text { 3. Number of } \\
\text { family members }\end{array}$} & $\leq 5$ People & 19 & $58 \%$ \\
\hline & > 5 People & 14 & $42 \%$ \\
\hline \multicolumn{2}{|l|}{ Total } & 33 & $100 \%$ \\
\hline \multirow{2}{*}{$\begin{array}{l}\text { 4. Number of } \\
\text { children }\end{array}$} & $\leq 2$ People & 23 & $70 \%$ \\
\hline & > 2 People & 10 & $30 \%$ \\
\hline \multicolumn{2}{|l|}{ Total } & 33 & $100 \%$ \\
\hline
\end{tabular}

TABLE II. THE RELATIONSHIP BETWEEN MOTHER'S EDUCATION AND FEEDING PATTERNS FOR UNDERNUTRITION AND MALNUTRITION CHILDREN

Feeding Pattern Total

Incorrect Correct

\begin{tabular}{ccccc}
\hline Education & Average & 7 & 2 & 9 \\
Good & 16 & 8 & 24 \\
Total & 23 & 10 & 33 \\
& & & \\
Spearman rank correlation, $r=0.108 ; \mathrm{p}=0.551$
\end{tabular}


TABLE III. THE RELATIONSHIP BETWEEN THE ECONOMY AND FEEDING PATTERNS FOR UNDERNUTRITION AND MALNUTRITION

\begin{tabular}{ccccc}
\hline & & Feeding Pattern & Total \\
& & Incorrect & Correct & \\
\hline Economy & Low & 17 & 0 & 17 \\
& Average & 6 & 7 & 13 \\
Good & 0 & 3 & 3 \\
Total & 23 & 10 & 33 \\
& & & \\
Spearman rank correlation, $r=0.727=0.000$
\end{tabular}

TABLE IV. THE RELATIONSHIP BETWEEN CULTURAL VALUES AND LIFESTYLE AND FEEDING PATTERNS FOR UNDERNUTRITION AND MALNUTRITION

\begin{tabular}{|c|c|c|c|c|}
\hline & & \multicolumn{2}{|c|}{ Feeding Pattern } & \multirow[t]{2}{*}{ Total } \\
\hline & & Incorrect & Correct & \\
\hline \multirow{3}{*}{$\begin{array}{l}\text { Cultural } \\
\text { values } \\
\text { and } \\
\text { lifestyle }\end{array}$} & Negative & 18 & 2 & 20 \\
\hline & Positive & 5 & 8 & 13 \\
\hline & Total & 23 & 10 & 33 \\
\hline Spear & $n$ rank co & ation, $r=$ & $.548 ; p=$ & \\
\hline
\end{tabular}

Table 4 demonstrates 18 respondents with undernutrition and malnutrition children at Puskesmas Sawah Pulo is the most dominating variable for cultural values and lifestyle. This number represents mother with negative category of cultural values and lifestyle related to their habit feeding pattern incorrectly. Based on the results of statistical analysis using Spearman's rho correlation test with $\alpha<0.05$ in correlation result gets value $=0.548$ and value $=0.001$. value $=0.001$ less than 0.05 , which means that the hypothesis is accepted.

Table 5 indicates that 33 respondents mothers having undernutrition and malnutrition at Puskesmas Sawah Pulo were dominated by mother who get average category in social and family support with feeding patterns inappropriately. Based on the results of statistical analysis using Spearman's rho correlation test with $\alpha<0.05$ in correlation result gets value $=0.318$ and value $=0.071$. value $=0.071$ is higher than 0.05 , which means that the hypothesis is rejected. The statistical results showed there is no relation between social and family support and feeding patterns.
TABLE V. THE RELATIONSHIP BETWEEN SOCIAL AND FAMILY SUPPORT AND FEEDING PATTERNS FOR UNDERNUTRITION AND MALNUTRITION CHILDREN

\begin{tabular}{ccccc}
\hline & & \multicolumn{2}{c}{ Feeding Pattern } & Total \\
& Incorrect & Correct & \\
\hline $\begin{array}{c}\text { Social } \\
\text { and } \\
\text { family } \\
\text { support }\end{array}$ & Low & 6 & 2 & 8 \\
& Average & 15 & 3 & 18 \\
& Tood & 2 & 5 & 7 \\
& Total & 23 & 10 & 33
\end{tabular}

Spearman rank correlation, $r=0.318=0.071$

TABLE VI. THE RELATIONSHIP BETWEEN TECHNOLOGY AND FEEDING PATTERNS ON UNDERNUTRITION AND MALNUTRITION CHILDREN

Feeding Pattern Total

Incorrect Correct

\begin{tabular}{rrccc}
\hline Technology & Low & 14 & 2 & 16 \\
& Average & 9 & 5 & 14 \\
Good & 0 & 3 & 3 \\
Total & 23 & 10 & 33
\end{tabular}

Spearman rank correlation, $r=0.466=0.006$

Table 6 demonstrates that at Puskesmas Sawah Pulo, mothers who have low and average technology contribute to apply feeding pattern inappropriately. Based on the results of statistical analysis using Spearman's rho correlation test with $\alpha$ $<0.05$ in correlation result gets value $=0.466$ and value $=$ 0.006 . value $=0.006$ is lower than 0.05 , which means that the hypothesis is accepted.

\section{DISCUSSION}

Statistical analysis indicates there was no correlation between education and feeding patterns at Puskesmas Sawah Pulo, June 2016. Most of the respondents have a good education with incorrect feeding patterns. Education is influenced by formal education. However, that does not mean someone who is less educated absolutely has less knowledge because an increase of knowledge can be gained through non-formal education [8]. Transcultural nursing theory states that health behavior is formed from a variety of factors that work together. If there is an imbalance factor, the health behavior becomes less. Despite having a good education, health behavior remains less [3]. Cultural values, beliefs and practices 
is difficult to change people's behavior [9]. There are other factors that cause feeding patterns applied by the respondent, which is not proper in implementation, so children are undernutrition or malnutrition. Having good education is not guarantee to them to apply the correct feeding pattern. Publics understand the information given by Puskesmas officer, but in practice, their feeding pattern is still not right.

Statistical analysis showed a significant relationship between the economy and feeding patterns. Most respondents have low economy background with incorrect feeding pattern. An increase income of household gives opportunity to improve the quality also increase the number and diversity of food that can be purchased. Family economic status will affect the attitude of mother in feeding right on families, especially children [10]. A person's behavior is influenced by economic status, which means behavioral which needs healthy life is influenced by the ability of family economically [11]. In feeding pattern of children, income is important because the better the economy of the family the easier to purchase food, and vice versa if the economy gets worse, the family purchasing power will be more difficult [12]. Mothers who have low economy level will be difficult to provide good nutrition to children so they can only provide food such as rice with vegetables even dishes is rarely to be varied, so it makes children undernutrition or malnutrition.

Statistical analysis indicates there is a significant relationship between cultural values and lifestyle and feeding pattern. Most respondents have negative cultural values and lifestyle with improper feeding patterns. Culture is as ideas, communications, actions, customs, beliefs, values, and customs of racial, ethnic, religious, or social [9]. Habits are formed by culture, it can affect the nutritional status and causes malnutrition [13]. Culture affects a person in deciding what to eat, how to process, how to prepare, and how to implement, as well as to whom and what conditions the food is consumed. The eating habit of a family is highly influenced by person's dietary which one's favorite eating habit depends on their family [14].

Cultural values and lifestyle in society affects a particular behavior especially in feeding patterns for toddler. Negative cultural values and lifestyle will cause improper feeding patterns, whereas if the value of a positive culture and lifestyle, will lead to the granting of the right foods.

Statistical analysis illustrates there is no relation between social and family support and feeding patterns. Most respondents have a social and family support average but improper feeding patterns. According to Taylor, support which is owned by the individual can prevent the growing problems faced by the pressure. Someone who obtains higher social support will overcome and face problems successfully than individual who does not receive support or obtain social support [15]. However, respondents who have average social and family support apply improper feeding patterns. A good social and family support is material / instrumental.

Statistical analysis indicates no significant relationship between technology and feeding patterns. Almost all of the respondents have less technology with improper feeding patterns. Technology is a facility that allows the individual to choose or get advice that can solve problems in health care [8]. The most fundamental causes of children's development is a socio-economic factor. These factors are education, occupation, household income, culture, and technology [16]. These factors collaborate each other so it can affect the nutrients consumed by children. The usage of technology is lacking in this study due to limited cost to access information and utilize the power tool to create a varied dietary so that feeding patterns applied to children is not appropriate. Awareness and willingness of each individual are also very instrumental in implementing proper feeding patterns in toddlers.

\section{CONCLUSION}

Education factor is not related to feeding patterns for undernutrition and malnutrition. It is caused by most respondents having good education, but in feeding behavior is not appropriate for children. Economic factor has correlation with feeding pattern for undernutrition and malnutrition. It is caused by most respondents having low economy so feeding patterns to children is not appropriate. Cultural values and lifestyle have correlation with feeding pattern for undernutrition and malnutrition. It is caused by most respondents having negative cultural values and lifestyle so feeding patterns to children is not appropriate.

Social and family support are not related to feeding pattern on undernutrition and malnutrition children. Most respondents have adequate social and family support, but the pattern of feeding to children is not appropriate. The technology relates to feeding patterns on undernutrition and malnutrition children. Most respondents who unable to utilize technology causes the feeding patterns to children incorrectly

\section{REFERENCES}

[1] World Health Organization, World Health Statistics. WHO, 2007.

[2] C. Ames, GE, Heckman, MG, Grothe, KB, "Eating SelfEfficacy: Development of a Short-Form WEL," Eat. Behav., vol. 13, pp. 375-378, 2012.

[3] M. Leininger, "Culture Care Theory: A Major Contribution to Advance Transcultural Nursing Knowledge and Practices," Transcult. Nurs. J., vol. 13, p. 189, 2002.

[4] C. Mwangome, M, Prentice, A, Plugge, E, Nweneka, "Determinants of Child Health and Nutrition Appropriate Practices Among Women in Rural Gambia," vol. 28, no. 2, pp. 167-172, 2010.

[5] The Ministry of Health of the Republic of Indonesia, Data and Information 2014: Indonesia Health Profile. 2015.

[6] K. Yulia, C, Sunarti, E, Roosita, "Pola Asuh Makan dan kesehatan Anak Balita pada Keluarga Wanita Pemetik The di PTPN VIII Pangalengan," J. Progr. Stud. Gizi Masy. dan Sumber daya Kel. Inst. Pertan. Bogor, vol. 11, no. 1, 2008.

[7] I. S. Lestari, Y. Kusumastuti, and K. E. Werdani, "Faktorfaktor yang mempengaruhi kesediaan wus dalam melakukan deteksi dini kanker serviks di puskesmas manahan surakarta," Universitas Muhammadiyah Surakarta, 2016.

[8] J. Giger and Davidhizar, Transcultural Nursing: Assesmentand Intervention. Canada: Year Book, 2013. 
[9] P. . Potter, A. . Perry, P. . Stockert, and A. . Hall, Fundamentals of nursing, 8th ed. St Louis Missouri: Elsevier Mosby, 2013.

[10] R. Liu and Venables, "Malnutrition at age 3 years and lower cognitive ability at age under 2 years," J. Compil., 2010.

[11] S. Notoatmodjo, Promosi Kesehatan dan Ilmu Perilaku. Jakarta: Rineka Cipta, 2007.

[12] Suhardjo, Pemberian Makanan pada Bayi dan Anak. Yogyakarta: Canisius, 2003.

[13] D. Booth and P. Booth, "Targeting Cultural Changes Supportive of The Healthiest Lifestyle Patterns," Appetite, vol. 56, pp. 210-221.
[14] Z. Arifin, "Gambaran Pola Makan Anak Usia 3-5 Tahun dengan Gizi Kurang di Pondok Bersalin Tri Sakti Balong Tani Kecamatan Jabon Sidoarjo,” Journal, vol. 1, no. 1, 2015.

[15] S. Taylor, Health Psychology. New York: McGraw Hill, 2003.

[16] I. Supariasa, B. Bakri, and I. Dawn, Penilaian Status Gizi. Jakarta: EGC, 2001. 